\title{
Biogas potential of organic waste onboard cruise ships - a yet untapped energy source
}

\author{
Kai Schumüller ${ }^{1}$ (D) $\cdot$ Dirk Weichgrebe $^{1} \cdot$ Stephan Köster $^{1}$ \\ Received: 19 June 2020 / Revised: 21 December 2020 / Accepted: 25 December 2020 / Published online: 20 January 2021 \\ (C) The Author(s) 2021
}

\begin{abstract}
To tap the organic waste generated onboard cruise ships is a very promising approach to reduce their adverse impact on the maritime environment. Biogas produced by means of onboard anaerobic digestion offers a complementary energy source for ships' operation. This report comprises a detailed presentation of the results gained from comprehensive investigations on the gas yield from onboard substrates such as food waste, sewage sludge and screening solids. Each person onboard generates a total average of about $9 \mathrm{~kg}$ of organic waste per day. The performed analyses of substrates and anaerobic digestion tests revealed an accumulated methane yield of around $159 \mathrm{~L}$ per person per day. The anaerobic co-digestion of sewage sludge and food waste (50:50 VS) emerged as particularly effective and led to an increased biogas yield by $24 \%$, compared to the mono-fermentation. In the best case, onboard biogas production can provide an energetic output of $82 \mathrm{~W} / \mathrm{P}$, on average covering 3.3 to $4.1 \%$ of the total energy demand of a cruise ship.
\end{abstract}

Keywords Anaerobic digestion $\cdot$ Biogas $\cdot$ Cruise ship $\cdot$ Food waste $\cdot$ Sewage sludge $\cdot$ Thermal energy

\section{Introduction}

In recent years, cruises have been very popular, and the industry has grown continuously for 20 years. As part of the globalisation, cruise ships have been spread over the whole world clustering in the most beautiful sites of the oceans. These include the most frequented regions, primarily the Caribbean and the Mediterranean [1]. The Cruise Liners International Association (CLIA) totals 19.1 million passengers for 2010 and records within 8 years growth about $50 \%$ to 28.5 million passengers in 2018 [1]. To meet this increasing demand, more and bigger cruise ships will be introduced within the next years; thus, for 2019, a total of 272 cruise ships were expected

Kai Schumüller

schumueller@isah.uni-hannover.de

Dirk Weichgrebe

weichgrebe@isah.uni-hannover.de

Stephan Köster

koester@isah.uni-hannover.de

1 Institute for Sanitary Engineering and Waste Management of the Leibniz Universität Hannover, Welfengarten 1,

30167 Hannover, Germany
[1]. As a consequence of this growing sector, its environmental impact increased with the number of cruise ships and passengers, not sparing the most attractive and sensitive areas.

A recent study for the Baltic Sea from Wilewska-Bien et al. [2] shows that only limited information about the handling management of food waste and wastewater onboard passenger vessels is provided through websites of the shipping companies. In the last years, the increasing number of scientific publications on cruise ship-generated solid waste points out a rising interest [3]. Thus, Sanches et al. [3] provide a crossdisciplinary overview of the recent situation of solid waste from cruise ships. However, no detailed information on organic waste was given. Innovative approaches were pursued by Toneatti et al. [4]. These authors reported on the optimisation of waste management onboard cruise ships for glass, paper and cellulosic waste and the recovery of energy embedded in the unavoidable paper and cellulosic waste through the exploitation of the incinerator's exhaust flue gas or through syngas production [4]. Nevertheless, Vaneeckhaute and Fazli [5] presented in a case study the best management practices for ship-generated food waste and sewage in the region of the Baltic Sea. For wastewater, these practices consider the discharge to adequate port reception facilities (PRF) or an advanced treatment onboard. Noteworthy is the suggested 
handling of food waste as it comprises the shore-based conversion into biogas.

On shore, the anaerobic digestion (AD) technology used for biogas generation can be classified as mature because it has been extensively tested and applied over decades. In essence, any organic residual material is potentially suited as a substrate for biogas production. For instance, sewage sludge is converted to biogas in municipal sewage treatment plants, principally to sustain the internal energy supply. In the context of renewable energies, the production of biogas has also increased substantially in agriculture; thus, energy crops such as maize and organic residues from animal farms are used as substrates. However, in several European countries, food waste is also used as a substrate, especially in municipal wastewater treatment plants (WWTPs) when spare capacity permits co-digestion $[6,7]$. In contrast, no implementation onboard vessels have been noted to date.

Cruise ships generate several tons of food waste every day. Sewage sludge and screening solids from the wastewater pretreatment further increase the organic residues. At present, the onboard management of organic residual materials only includes steps related to disposal. Prior to disposal, the food waste is shredded and homogenised. For final discharge to PRFs or incineration onboard, both food waste and sewage sludge require dewatering and drying to reduce the volume. The volume-reducing steps do not apply if the residues are legally disposed of at sea after shredding. This option is still used to a significant extent and is permitted within the legal framework of the international MARPOL convention (Annex V) [8]. For example, Carnival Corporation, the world's largest cruise company, disposed of 106,000 $\mathrm{t}$ of food waste at sea in 2015. This corresponds to $22 \%$ of the total waste generated onboard [9], confirming the findings of Strazza et al. [10]. The actual handling of ship-generated organic waste varies from ship to ship. Figure 1 illustrates possible paths and treatment steps of organic waste on modern cruise ships, considering the onboard WWTP. Vacuum piping systems are state of the art onboard and ensure sufficient mass transfer with minimal water demands. Both streams, organic waste and sewage are closely linked onboard. In particular, existing plants may have different or modified processes and procedures since cruise ships are equipped with different system solutions from different manufacturers and development stages. To exemplify, the Alaska Department of Environmental Conservation [11] assembled an overview of advanced wastewater treatment systems used on vessels in Alaska.

Currently, several cruise lines are aiming to increase the level of environmental protection on their ships. For instance, all new cruisers will come with "advanced wastewater treatment systems" [12], while the performance of these onboard systems does not reach state-of-the-art onshore treatment quality, yet. Improved environmental protection onboard can offer advantages if efficiency is increased, fossil fuels are substituted and organic as well as nutrient loads originating from waste streams are reduced. Anaerobic digestion as well as the associated biogas production and utilisation meet these criteria to a laudable extent. Until 2009, any use of fuel gases onboard ships was strictly forbidden or highly regulated, which prevented the onboard implementation of anaerobic technology. So far, biogas production onboard has not been considered as an available opportunity by shipbuilders or cruise lines. Now, with the approval of liquefied natural gas (LNG) as fuel and the introduction of gas-powered combustion engines onboard, it is possible to use gas as fuel [13]. This fact enables the application of anaerobic technology onboard to exploit a yet unused energy source. But, a specific legal classification for the onboard implementation of a biogas plant is not feasible, yet. To date, ship-specific feasibility studies have only been initiated in isolated cases, e.g. from Hudde and Orth (unpublished). To the best of the authors' knowledge, a comprehensive and fundamental investigation, which provides sufficient data on ship-generated biogas substrates, including corresponding biogas and energy potential, has not yet been carried out.

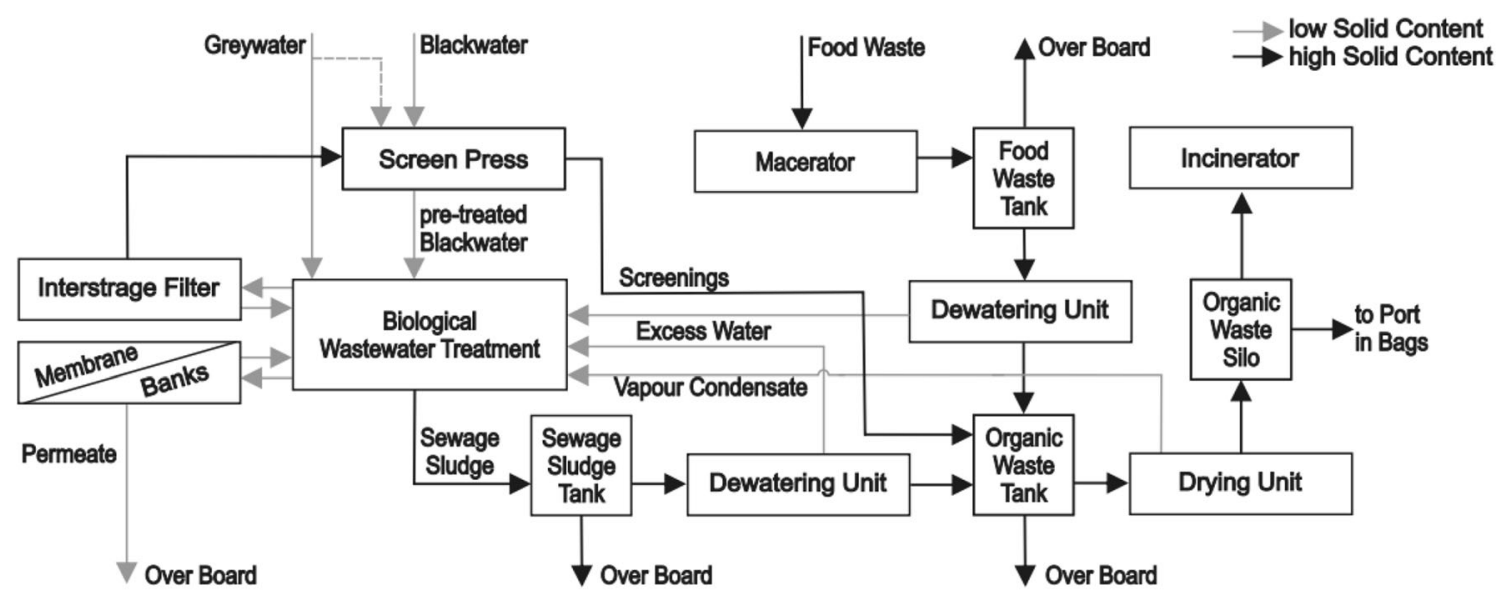

Fig. 1 Simplified illustration of the current handling of organic waste onboard modern cruise ships, considering the WWTP (dashed line: optional) 
This paper gives first detailed insights of onboard accruing organic waste that can be valorised to biogas, focusing on food waste and sewage sludge. Besides quantification, a detailed characterisation of the substrates will be accomplished to provide sufficient information to derive potential energy yields and to design future adapted biogas plants onboard cruise ships. All results originate from the cooperative R\&D project "Cruise Liners: Efficient onboard Anaerobic digestioN of organic wastes for energy recovery" (CLEAN), which has been investigating anaerobic digestion technology onboard cruise ships since August 2017.

\section{Materials and methods}

For this analysis, existing knowledge on the occurrence and management of organic waste onboard cruise ships is summarised and combined. However, further information is needed to undertake a comprehensive investigation. Therefore, additional samples have been collected onboard and corresponding substrate characterisations have been conducted. Where ship-related data were not available in the literature or through our onboard investigations, previous studies focusing on land-based anaerobic digestion (AD) were deferred to. Data describing AD processes are highly abundant.

\subsection{Literature review}

The relevant literature was reviewed by focussing on topics such as "Waste and wastewater onboard cruise ships" and "Anaerobic (co-)digestion". As already noted, currently no anaerobic digestion plants exist onboard cruise ships; hence, there is a dearth of academic literature in this regard. However, there is one unpublished cruise ship-related feasibility study conducted by Hudde and Orth on behalf of a cruise line. Relevant sources in the context of cruise ships are limited to information on the quantities of organic waste streams. Only a few provide specific per capita data on food waste generation onboard, e.g. Wilewska-Bien et al. [14], Olson [15], EMSA [16], Strazza et al. [10] and Polglaze [17]. Sampling reports of four cruisers, created by the US Environmental Protection Agency, are the sole source for onboard accruing sewage sludge and screening solids [18-21].

No further studies appear to provide detailed data and information concerning the quantitative accumulation of sewage sludge or screening solids onboard. For that reason, a rough person-specific calculation of the expected amount of excess sludge (sewage sludge) from the WWTP onboard was carried out in accordance with the recent German design standard A131 [22] for single-stage activated sludge plants, including upstream denitrification. Köster et al. [23] provide data concerning wastewater composition onboard as a mix of grey and black water, which constitutes the basis for calculations of person-specific sewage sludge generation rates (Table 1). The considered wastewater temperature was $20^{\circ} \mathrm{C}$, which is the limit temperature for the guideline A131. Amounts of screening solids were derived, considering the expected removal efficiency of a screen press used onboard and the TSS load per capita per day (Table 1).

In addition to publicly accessible literature and data, comprehensive information on a cruise ship fleet was provided by a cruise line company. Besides piping and instrumentation diagrams of the waste and wastewater treatment for two ships, numbers of passenger and crew and data on sewage sludge and food waste generation were provided. Two cruise ship types were investigated with an occupancy ranging from 2500 to 5000 people, labelled as types A and B.

\subsection{Selection and sampling of substrates}

The CLEAN research project ensured access to different cruise ships, with sampling conducted on six dates on three cruise ships in total. Together with the crew, suitable sampling points were considered and selected. The samples included food waste (FW) separated by origin (passengers, crew, dewatered), sewage sludge (SS) from membrane-based wastewater treatment plants and screening solids from the mechanical wastewater pre-treatment. Depending on sample heterogeneity, the amount of substrate sampled rises to a maximum of $30 \mathrm{~kg}$. Because of accessibility constraints in the engine room, only three sewage sludge samples and one sample of screening solids were taken. Furthermore, operational information was provided by the cruise line. FW was sampled manually in the different galleys. Thus, these samples represent direct leftovers and overproduced food, originating from the buffet-service for passengers and crew members. Following TUI Cruises \& Futouris [26], this comprises already about $80 \%$ of the total onboard produced $\mathrm{FW}$ amounts. Sampling from the food waste collection tank which is part of the onboard vacuum disposal system was not operationally feasible during the period of data collection. For optimal sample conditioning, first, pre-homogenisation was carried out. Where sample analysis was not due to take place within the next $72 \mathrm{~h}$, the relevant samples were stored at $-20{ }^{\circ} \mathrm{C}$. Depending on the targeted laboratory procedure, the samples were homogenised through a regular commercial blender and/or a high-speed disperser (Ultra-Turrax) and diluted as required. Figure 2 shows three of the sampled substrates.

\subsection{Data evaluation}

\subsubsection{Food waste}

Detailed data on the filling level of the single food waste tank onboard a cruise ship for an evaluation period of 8 days were 
Table 1 Wastewater pollutant load per person onboard cruise ships as a mixture of BW and GW (BW: black water, GW: grey water) as the basis for the calculation of the resulting amount of sewage sludge

\begin{tabular}{llll}
\hline Parameter & Unit & $\begin{array}{l}\text { Wastewater mix (BW } \\
+ \text { GW); Köster et al. [23] }\end{array}$ & $\begin{array}{l}\text { Screen press removal } \\
\text { efficiency }(\%)\end{array}$ \\
\hline $\mathrm{COD}$ & $\mathrm{g} /(\mathrm{P} \cdot \mathrm{d})$ & 350 & $35^{\mathrm{a}}$ \\
$\mathrm{TSS}$ & $\mathrm{g} /(\mathrm{P} \cdot \mathrm{d})$ & 139 & $35^{\mathrm{a}}$ \\
$\mathrm{NH}_{4}-\mathrm{N}$ & $\mathrm{g} /(\mathrm{P} \cdot \mathrm{d})$ & 18.5 & 0 \\
$\mathrm{TN}$ & $\mathrm{g} /(\mathrm{P} \cdot \mathrm{d})$ & 24.5 & 8.6 \\
$\mathrm{TP}$ & $\mathrm{g} /(\mathrm{P} \cdot \mathrm{d})$ & 2.8 & $14^{\mathrm{b}}$ \\
$\mathrm{Q}$ & $\mathrm{L} /(\mathrm{P} \cdot \mathrm{d})$ & 251 & - \\
\hline
\end{tabular}

${ }^{\mathrm{a}}$ Tchobanoglous et al. [24]; ${ }^{\mathrm{b}}$ Henze and Comeau Y. [25]

provided. First, a transformation into $\mathrm{m}^{3}$ was conducted. Second, it was assumed that FW has a density of $1 \mathrm{~kg} / \mathrm{L}$, in accordance with US EPA [19]. Furthermore, the total amount of FW generated within the evaluation period was set to $100 \%$. Thus, accruing FW is expressed in percentage of the total FW. The person-specific FW generation rates were derived, considering the actual number of persons onboard.

\subsubsection{Sewage sludge}

Data sets of five cruise liners were available, containing information on de-sludge amounts per day and corresponding total suspended solids (TSS) values of the bioreactor as part of the wastewater treatment plant onboard. These data enabled the calculation of sewage sludge (SS) amounts per capita per day, considering the actual number of persons onboard.

\subsection{Laboratory analyses}

The analyses undertaken for standard parameters are specified in Table 2.

Furthermore, four food waste samples were sent to an accredited service laboratory, LUFA Nord-West, to carry out proximate analysis. Under VO (EG) 152/2009 Annex III, the resulting parameters can be specified as dry mass, crude ash (CA), crude protein (CP), crude lipids (CL), and carbohydrates $(\mathrm{CH})$ split into nitrogen-free extracts (NFE) and crude fibre (CF). Additionally, ultimate analyses $(\mathrm{C}, \mathrm{H}, \mathrm{O}, \mathrm{N}, \mathrm{S})$ for five food waste samples were conducted by the accredited service laboratory AWV-Dr. Busse GmbH. Used methods were in accordance with the European standards: EN 154143:2007, EN 13137:2001 EN 15408:2011, EN 15407:2011, EN 15407:2011. Due to irregularities in two of five samples, an extra validation of the laboratory results has been conducted. For validation, the results of the proximate analysis were converted into its elementary composition by following the average elementary composition for the main components lipids, proteins and carbohydrates from Straka et al. [29]. Thus, the results of the proximate analysis served as validation reference.

Based on the elemental composition, the theoretical COD content $\left(\mathrm{COD}_{\text {theo. }}\right)$ of food waste was calculated in accordance with OECD Guideline 301, annexe IV [30]. By taking into account that $350 \mathrm{~mL}$ of methane are stoichiometrically obtained per gram of metabolised COD, the theoretical methane yield was derived.

\subsection{Anaerobic digestion tests}

Considering the German guideline VDI 4630 [31] and Holliger et al. [32], anaerobic lab-scale batch tests were carried out. These biochemical methane potential (BMP) tests were used for $\mathrm{FW}, \mathrm{SS}$ and screening solids with a duration of up to 30 days at a temperature of $35^{\circ} \mathrm{C}$. Two types of BMP assays, volumetric $(500 \mathrm{~mL}$ bottles $)$ and manometric (1000 mL bottles) gas measurements, were used. Anaerobic sludge from the municipal wastewater treatment plant digester in Hanover-Herrenhausen (Germany) served as inoculum. Before applying, the inoculum was pre-incubated for 1 week. Every test run was carried out in triplicates and with an inoculum-substrate ratio of two, in terms of VS. To ensure anaerobic conditions, the head space of each bottle was flushed with nitrogen prior to incubation. Furthermore, blank assays with inoculum, but no positive controls were conducted. Positive controls in both test systems were performed once for validating, which showed a result deviation of $4 \%$. While the used volumetric measured BMP test only revealed biogas results, the manometrically measured BMP test provided data on methane content by analysing the headspace with a gas
Fig. 2 Substrates onboard cruise ships: (left) food waste; (centre) dewatered food waste; (right) sewage sludge

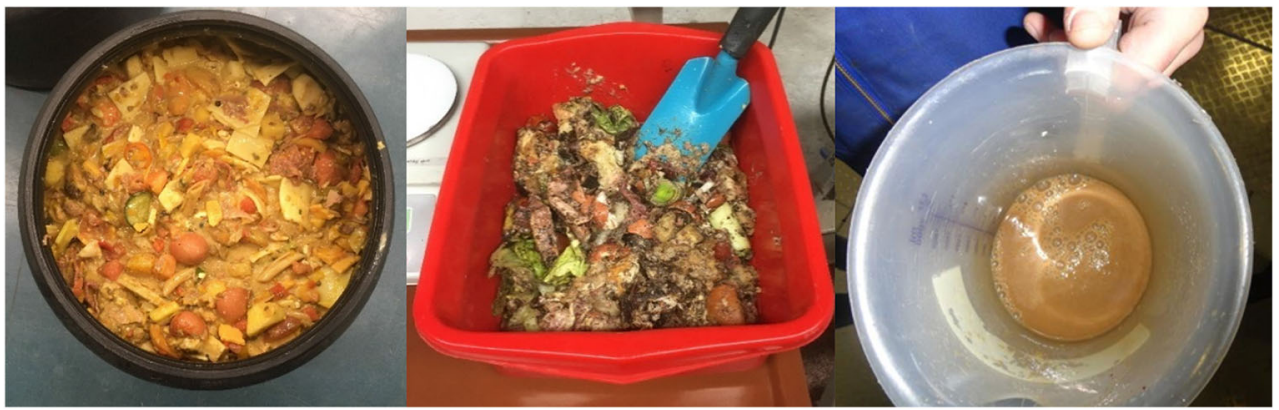


Table 2 Analysed standard parameters, detection standards and methods

\begin{tabular}{ll}
\hline Parameter & Detection standard/method \\
\hline Total solids (TS) & EN 12880:2001 [27] \\
Volatile solids (VS) & EN 15935:2012 [28] \\
pH value & inoLab - pH 7310 Set 2 \\
Chemical oxygen demand (COD) & Cuvette tests Hach-Lange: LCK 514 \\
Ammonium nitrogen $\left(\mathrm{NH}_{4}-\mathrm{N}\right)$ & Cuvette tests Hach-Lange: LCK 303 \\
Total nitrogen (TN) & Cuvette tests Hach-Lange: LCK 238 \\
\hline
\end{tabular}

chromatograph (GC: Shimadzu GC-2014; column: Hayesep Q, mesh 80/100) at the end of each experiment. All results have been converted to dry gas under standard conditions (273.15 K; 1013 mbar).

\subsection{Reference cruise ship}

Besides determining person-specific details, an average reference cruise ship size with a total capacity of 3000 people onboard was chosen for this study. This allowed describing the ship's scale and quantifying the biogas and energy potentials. Moreover, the environmental impact of onboardgenerated organic waste can be depicted. The chosen cruise ship size is based on the following data of the world's biggest cruise line company Carnival Corporation \& plc [33]:

Passenger capacity:

Fleet size:

Ratio passenger/crew (estimated):

Passenger per cruise ship:

Crew members per cruise ship:

Due to variations in passenger numbers and largely fix personnel, passenger-crew ratio varies typically from 2 to 4 . Further deviations are caused by ship type and cruise company.

The mass balance for the reference cruise ship (Fig. 7) is based on the person-specific generation rates from Table 6, the biogas and methane yields from Table 8 and the COD substrate parameter based on volatile solids from Table 7. For screening solids, the COD content was derived according to the removal efficiency of the screen press in Table 1.

\section{Results and discussion}

\subsection{Quantity and availability of substrates}

The substrates available for biogas production introduced above are specified in terms of their volume and properties.
For that purpose, information from the literature is pooled with the data collected for this study.

\subsubsection{Food waste}

Onboard FW can be classified into four categories: overproduction, plate leftovers, galley waste, and expired food. Regarding the generation of food waste (FW) onboard, significant differences can be revealed. Table 3 summarises the specific generation per person, and further breaking down per passenger and crew member, including specifications on the total and volatile solids. The analysis of a data set on food waste for 8 days on one specific cruise ship resulted in an amount of $1.365 \mathrm{~kg}$ on average per person per day. In contrast, literature references state higher rates from 1.4 to $3.5 \mathrm{~kg} \mathrm{FW}$ per person per day (Table 3). Only Wilewska-Bien et al. [14] provided concrete data for the $\mathrm{FW}$ generation rate for crew members with $0.36 \mathrm{~kg} /(\mathrm{P} \cdot \mathrm{d})$, while passenger-related FW generation was estimated based on literature data. Design rates from the investigated ship operator range from 1.6 to $2 \mathrm{~kg}$ / $(\mathrm{P} \cdot \mathrm{d})$. In view of a ratio of 3:1 for passengers and crew members, a general FW generation rate per person per day can be derived. Considering a FW production of $0.36 \mathrm{~kg} /(\mathrm{P} \cdot \mathrm{d})$ for crew member and $1.365 \mathrm{~kg} /(\mathrm{P} \cdot \mathrm{d})$ in general allows calculating a passenger $\mathrm{FW}$ rate of $1.7 \mathrm{~kg} /(\mathrm{P} \cdot \mathrm{d})$.

TS of the sampled FW for passengers and crew members was 22.9 wt.- $\%$ and 33.1 wt.- $\%$ and VS/TS accounted for $87.4 \%$ and $85.9 \%$, respectively. Despite a dewatering step, no significant difference to passengers' FW can be declared for dewatered food waste. According to the ship operator, no water is added to the FW for further processing. The high solid content for crew FW is fully in line with findings of Wilewska-Bien et al. [14]. Sticking to the passenger:crew ratio, $93.4 \%$ of the total food waste is produced by passengers, while only $6.6 \%$ is assigned to crew members. Thus, crew FW plays only a minor part onboard cruise ships.

Figure 3 presents the daily variations of accruing FW during the evaluation period of 8 days onboard cruiser 2. Personspecific FW rates diverge -20 to $+29 \%$ from the average while the trendline for accumulated FW develops linearly with an $R^{2}$ of 0.9971 . Considering different day types like cruise, port and changeover days no consistent picture can be identified. The first 4 days included port stays with a duration of 7 to $11 \mathrm{~h}$, with the lowest FW amount on day one. A high-FW day on day 5 (cruise) is followed by a below-average day (changeover), followed by a cruise day with an average FW generation. Sufficient storage volume of the actual food waste tank may compensate fluctuating FW amounts, since only $60 \%$ tank volume is used on average. Hence, a constant FW supply per day can be ensured.

Figure 4 shows 24-h trends of onboard-generated FW. Significant peaks are at breakfast (7:00-11:00) and dinner (20:00-23:00). Additionally, on cruise days and on the 
Table 3 Person-specific generation rate of FW onboard cruise ships

\begin{tabular}{|c|c|c|c|c|c|c|c|c|c|c|c|}
\hline & \multicolumn{3}{|l|}{ Sampling } & \multirow{2}{*}{$\begin{array}{l}\text { Dataset } \\
\text { Cruiser } 2 \text { type B }\end{array}$} & \multicolumn{6}{|l|}{ Literature } \\
\hline \multicolumn{2}{|c|}{ Data source } & \multicolumn{3}{|c|}{3 cruisers types A \& B } & & \multirow{2}{*}{$\begin{array}{l}\text { Ship operator } \\
\text { Person }\end{array}$} & \multicolumn{2}{|c|}{$\begin{array}{l}\text { Wilewska-Bien } \\
\text { et al. [14] }\end{array}$} & \multirow{2}{*}{$\begin{array}{l}\text { Olson [15] } \\
\text { Person }\end{array}$} & \multirow{2}{*}{$\begin{array}{l}\text { EMSA [16] } \\
\text { Passenger }\end{array}$} & \multirow{2}{*}{$\begin{array}{l}\text { Toneatti et al. [4] } \\
\text { Person }\end{array}$} \\
\hline Parameter & Unit & Passenger & Crew & Dewatered & Person & & Passenger & Crew & & & \\
\hline Data size & - & $n=5$ & $n=4$ & $n=3$ & $n=8 \mathrm{~d}$ & - & - & 3 & - & - & - \\
\hline $\mathrm{g}_{\text {Substrate }}$ & $\frac{\mathrm{kg}}{P \cdot d}$ & - & - & - & 1.365 & $1.6-2.0$ & 2 & 0.36 & $1.4-2.4$ & $\leq 3.5$ & $2.0-2.4$ \\
\hline$\varnothing \mathrm{TS}$ & wt.-\% & 22.9 & 33.1 & 23.2 & - & 10.0 & - & 29.1 & - & - & 20 \\
\hline$\varnothing \mathrm{VS} / \mathrm{TS}$ & $\%$ & 87.4 & 85.9 & 89.2 & - & - & - & - & - & - & - \\
\hline
\end{tabular}

changeover day, peaks at lunch (13:00-16:00) can be identified. Minimal food waste amounts show up from 15:00 to 20:00 and 00:00 to 03:00. Due to a comprehensive food supply onboard, FW accrues throughout the whole day with periods of high and low volume. This may be caused by the preparation of mealtimes, FW disposal afterwards and FW of additionally operating snack bars.

A study on food waste reduction from TUI Cruises \& Futouris [26] states that $51 \%$ of the FW is related to overproduction, while $29 \%, 18 \%$ and $2 \%$ are related to plate leftovers, galley waste and expired food, respectively. Here, food overproduction is the biggest issue to tackle. Food overproduction describes preventively prepared food that has not been consumed, e.g. in buffet-based restaurants and food that was prepared but remained in the galley. Proposals acquired within this report to reduce FW involve means like changing buffet equipment, changes in refill behaviour and open communication with passengers. As consequence, a reduction of $17.4 \%$ was achieved [26]. Reducing food waste onboard is only possible to a limited extent without disrupting the expected marine holiday atmosphere. A reduction of $17.4 \%$ would decrease the FW generation for passengers to $1.4 \mathrm{~kg} /(\mathrm{P} \cdot \mathrm{d})$ and save about $300 \mathrm{~g}$ food (waste) per day per passenger.

Regarding the hospitality sector onshore, a survey of ten restaurants in the UK reports an average FW generation of about $0.48 \mathrm{~kg}$ per served person ( $n=1247$ meals) [34]. Similar findings were also presented by Papargyropoulou et al. [35] for the hospitality sector in Malaysia where on average $0.53 \mathrm{~kg} \mathrm{FW}$ per meal was produced. In this connection, a five-star hotel restaurant meant for tourists had the highest FW amount with more than $1 \mathrm{~kg} / \mathrm{cus}-$ tomer. Transferring these outcomes to an onshore hotel resort with full board service that considers at least three meals per day per person, a specific FW production rate of about $1.5 \mathrm{~kg} /(\mathrm{P} \cdot \mathrm{d})$ can be derived. This result is similar to the calculated $\mathrm{FW}$ production rate onboard of $1.7 \mathrm{~kg} /(\mathrm{P} \cdot \mathrm{d})$. Therefore, it stands to reason that the hotel industry onshore and on cruise ships might generate similar amounts of FW per person.

Compared to common households ashore, FW generation onboard is significantly higher. Jörissen et al. [36] give an overview for household FW in six European countries with a minimum volume of $153 \mathrm{~g}$ in Austria and a maximum volume of $1500 \mathrm{~g}$ in Germany per capita per week. The reason for these distinct variations was explained with changing FW definitions, which may include only edible food waste or every food-related waste like kitchen waste, excluding packaging waste [36]. For this potential analysis, the latter appears to fit the above-presented definition. However, onboard food waste production for passenger is at least eight times higher when compared to common households. Extrapolated for 3000 people accommodated on a cruise ship, the FW volume results in a household-equivalent of 19,000 inhabitants, a socalled small city.
Fig. 3 Trend of accumulated food waste during the evaluation period and corresponding personspecific food waste rates onboard cruiser 2

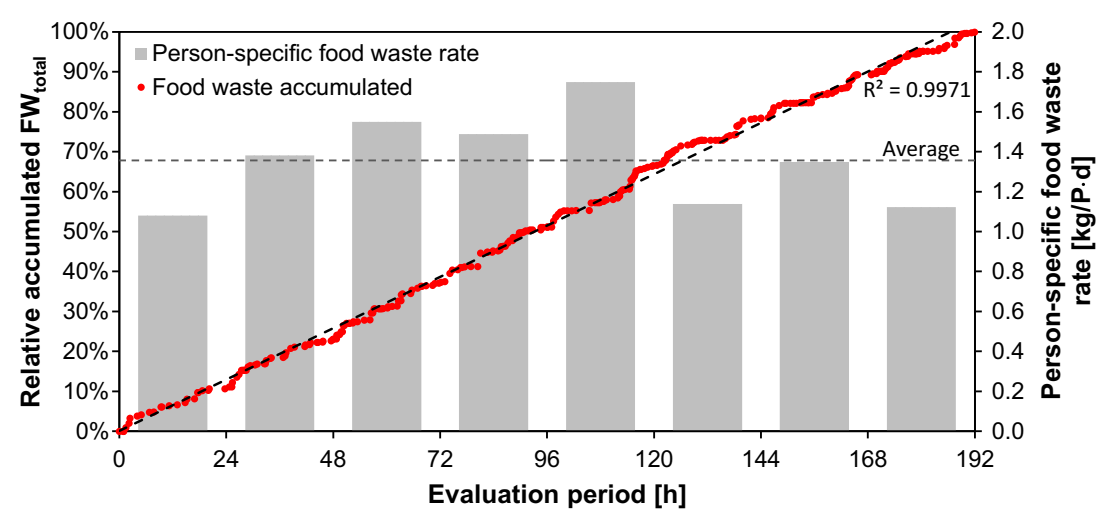


Fig. 4 Separated diurnal flow of accumulated food waste during the evaluation period of 8 days onboard cruiser 2 (grey: port day, black: cruise and changeover day)

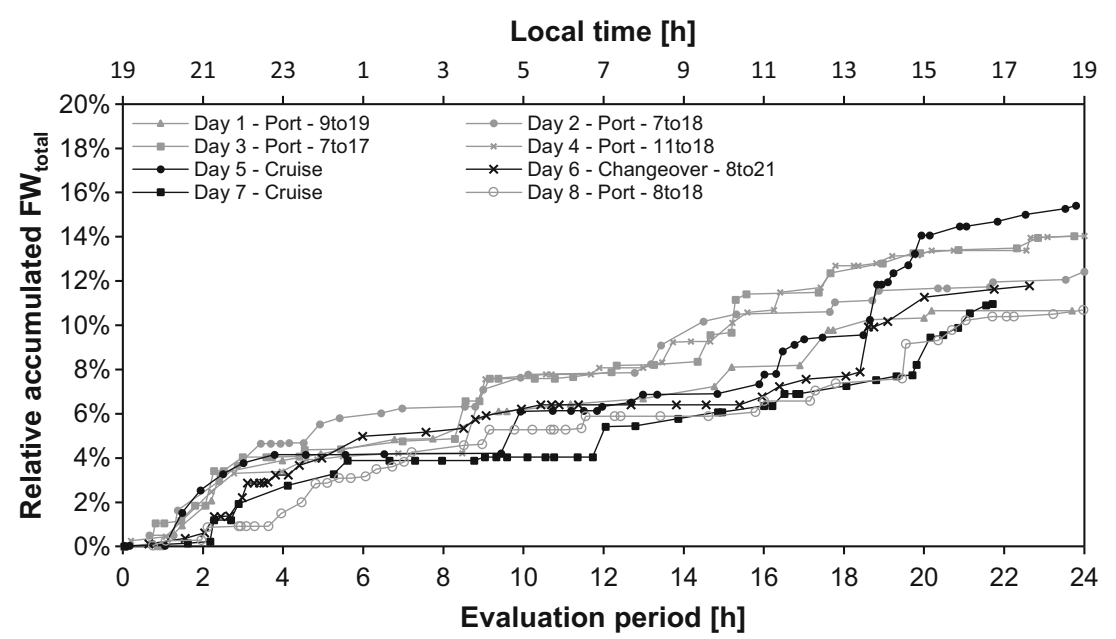

\subsubsection{Sewage sludge}

Sewage sludge (SS) is waste-activated sludge that originates from onboard biological wastewater treatment. The quantity of sewage sludge to be disposed of is mainly determined by the water content of the excess sludge, and the available dewatering facilities onboard. Because of its high water content, SS represents the biggest volumetric fraction of the onboard-generated substrates. Table 4 presents an overview of person-specific SS amounts and corresponding solid contents. In compliance with the effluent standards that are required for certification of a sewage treatment plant for special areas (MEPC.227(64)), the calculated sludge production rate of $97 \mathrm{~g} \mathrm{TSS} /(\mathrm{P} \cdot \mathrm{d})$ leads to a daily SS generation of $8.81 \mathrm{~kg} /$ $(\mathrm{P} \cdot \mathrm{d})$, considering a TSS of $1.1 \mathrm{wt} .-\%$. On the other hand, analysing data sets of five cruise ships revealed a wide spectrum of SS generation from 33 to $169 \mathrm{~g} \mathrm{TSS} /(\mathrm{P} \cdot \mathrm{d})$. However, the data sets of two cruise ships contained a comprehensive evaluation period of 180 and 218 days. Thus, the resulting and profound SS generation for these vessels was $97 \mathrm{~g} \mathrm{TSS} /(\mathrm{P} \cdot \mathrm{d})$ and $169 \mathrm{~g} \mathrm{TSS} /(\mathrm{P} \cdot \mathrm{d})$ on average and consequently within the upper range. A similar spectrum was presented by the US EPA for four cruisers while in Alaska waters, ranging from $8 \mathrm{~g}$ TSS/(P·d) up to $143 \mathrm{~g}$ TSS/(P·d) [18-21]. Here, it must be noted that the US EPA only considered single grab samples and typical SS amounts per day reported by the crew. Overall, three out of the nine considered cruise ships were in the range of the predicted sludge amounts.

Typical sludge production rates for municipal WWTPs onshore are in a range of $30 \mathrm{~g} \mathrm{TSS} /(\mathrm{P} \cdot \mathrm{d})$ and, therefore, roughly three times lower than onboard [37]. Comparing the personspecific wastewater pollutant loads onboard (Table 1) with pollutant loads in domestic wastewaters from Friedler et al. [38] reveals a two to three times higher COD and TSS load per person per day onboard. This may explain the significantly higher SS generation on cruise ships.

Various reasons may explain the wide range of SS generation rates onboard cruise ships. Firstly, numerous advanced wastewater treatment systems exist, which are based mainly on membrane technology, but also comprise flotation systems or reverse osmosis units for side stream treatment. Secondly, not all wastewater streams occurring onboard are always treated, since only black water is formally defined as sewage [39]. This results in clearly varying loads for the WWTP. Thirdly, the plant operation onboard is not consistent, due to a regularly shifting and limited crew staff. Thus, operational problems will be fixed individually. As an example, Fig. 5 and Fig. 6 illustrate differences in the occurrence of SS. While cruiser 1

Table 4 Person-specific generation rate of SS onboard cruise ships

\begin{tabular}{|c|c|c|c|c|c|c|c|c|}
\hline \multirow{2}{*}{$\begin{array}{l}\text { Data source } \\
\text { Parameter }\end{array}$} & \multirow[b]{2}{*}{ Unit } & \multirow{2}{*}{$\begin{array}{l}\text { Literature }^{\mathrm{a}} \\
\text { Calculation }^{\mathrm{b}}\end{array}$} & \multirow{2}{*}{$\begin{array}{l}\text { Sampling } \\
2 \text { cruiser type A }\end{array}$} & \multicolumn{5}{|l|}{ Datasets } \\
\hline & & & & Cruiser 1 type A & Cruiser 2 type B & Cruiser 3 type B & Cruiser 4 type B & Cruiser 5 type B \\
\hline data size & - & $n=\infty$ & $n=3$ & $n=180 \mathrm{~d}$ & $n=218 \mathrm{~d}$ & $n=31 \mathrm{~d}$ & $n=31 \mathrm{~d}$ & $n=17 \mathrm{~d}$ \\
\hline $\mathrm{g}_{\text {Substrate }}$ & $\frac{\mathrm{kg}}{\mathrm{P} \cdot \mathrm{d}}$ & 8.81 & - & 9.24 & 13.85 & 2.98 & 3.33 & 7.40 \\
\hline $\mathrm{g}_{\text {Substrate,dry }}$ & $\frac{\mathrm{g} \text { TSS }}{\mathrm{P} \cdot \mathrm{d}}$ & 97 & - & 97 & 169 & 45 & 33 & 97 \\
\hline$\varnothing \mathrm{TSS}$ & wt.- $\%$ & $1.1^{\mathrm{e}}$ & $1.32^{\mathrm{d}}$ & 1.05 & 1.22 & 1.51 & 0.99 & 1.31 \\
\hline$\varnothing \mathrm{VS} / \mathrm{TS}$ & $\%$ & $60-85^{\mathrm{c}}$ & 85.1 & - & - & - & - & - \\
\hline
\end{tabular}

${ }^{\mathrm{a}}$ Köster et al. [23]; ${ }^{\mathrm{b}}$ DWA [22]; ${ }^{\mathrm{c}}$ Tchobanoglous et al. [24]; ${ }^{\mathrm{d}}$ measured as TS; ${ }^{\mathrm{e}}$ assumption 
Fig. 5 Amount of sewage sludge per day and corresponding TSS concentration during evaluation period onboard cruiser 1

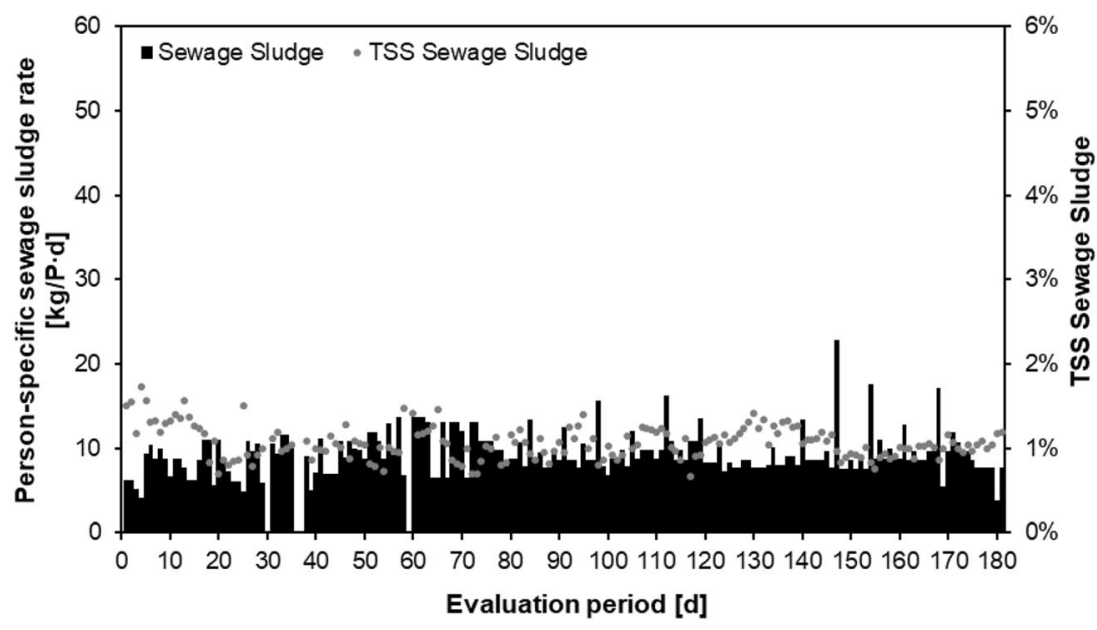

de-sludges consistently SS every day, cruiser 2 de-sludges inconsistently ranging from once per day to every fifth day with higher sludge amounts. The gap in Fig. 6 is related to a maintenance stay at the yard.

For the future, CLIA declared that every new cruise ship will be equipped with an advanced wastewater treatment plant [12]. Thus, sewage sludge amounts from wastewater treatment will occur successively on more cruise ships.

Utilising SS as second main feedstock for biogas production, a constant supply is required, too. Therefore, the figures above need to be considered for a sufficient substrate supply or sufficient storage volume. While the SS storage tank of cruiser 1 could take up a daily generation of up to $11.7 \mathrm{~kg} /$ $(P \cdot d)$, cruiser 2 has no separated SS storage tank. Instead, a biosludge tank collects both SS and screening solids. The daily average generation of SS alone would correspond to $110 \%$ biosludge tank storage volume. To ensure a constant SS volume per day for a biogas plant, a steady and daily desludge can be recommended.

However, to ensure sufficient storage volume and adjusting the water content for the AD, a dewatering step could easily reduce the accruing water volume by more than $50 \%$.
Typically, sludge dewatering units are integrated onboard, where a TS of up to 30 wt.-\% can be expected. Reducing the water volume by $75 \%$ means tripling the TS content. Thus, a SS with 1.1 wt.-\% TS would be adjusted to 3.2 wt.- $\%$ TS. In general, thickened SS for AD varies from 3 to 8 wt.-\% [37]. The separated excessive water can be reinputted into the onboard sewage treatment process. Modern cruise ships may already ensure a sufficient and constant substrate supply if an adapted sludge removal concept and a dewatering step are implemented.

\subsubsection{Screening solids}

Screening solids arise as a result of the mechanical treatment of wastewater. Commonly used onboard systems are coarse screens, vibrating screens or screen presses [11]. Depending on the installed equipment, wet or dry screening solids occur [40] and are collected separately or mixed in holding tanks, discharged at the port or to sea or incinerated onboard. On account of their origin, screening solids can be classified as a kind of primary sludge and act as the third main feedstock for the pursued onboard AD. The gathered data are shown in
Fig. 6 Amount of sewage sludge per day and corresponding TSS concentration during evaluation period onboard cruiser 2

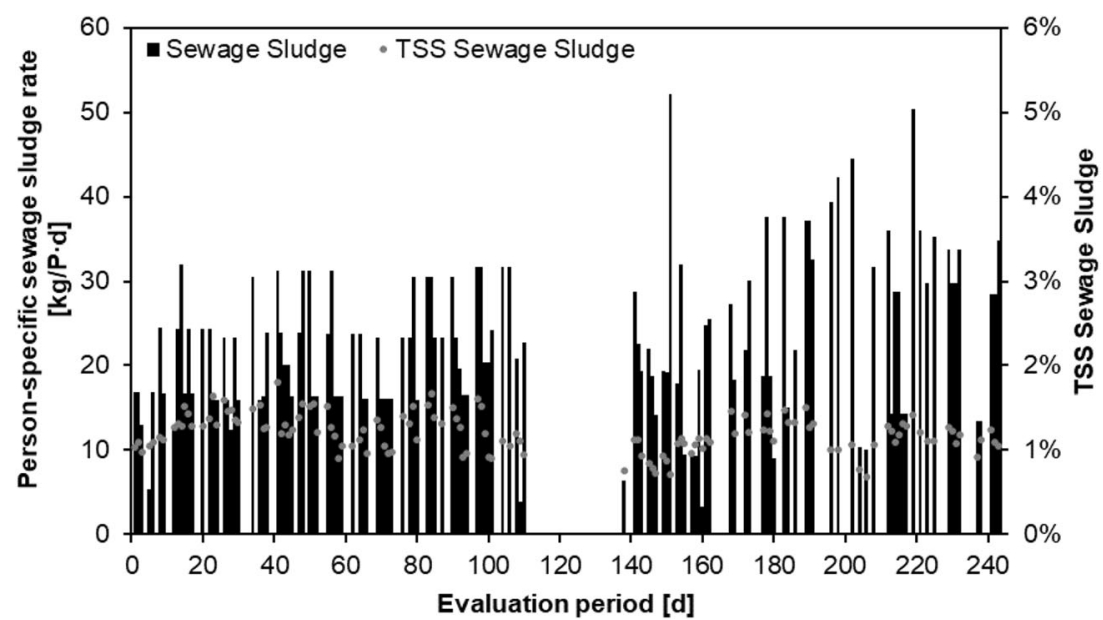


Table 5 Person-specific generation rate of screenings solids onboard cruise ships

\begin{tabular}{llcccc}
\hline $\begin{array}{l}\text { Data source } \\
\text { Parameter }\end{array}$ & Unit & Sample & Calculation & Ship operator & $\begin{array}{l}\text { Literature } \\
\text { Primary sludge }\end{array}$ \\
\hline Data size & - & $n=1$ & - & - & - \\
gSubstrate & $\frac{\mathrm{g}}{\mathrm{P} \cdot \mathrm{d}}$ & - & 122 & - & $583-4500^{\mathrm{a}}$ \\
gSubstratedry $^{\text {g TS }}$ & $\frac{\mathrm{g} \mathrm{TS}}{\mathrm{P} \cdot \mathrm{d}}$ & - & 49 & $35-45$ & $35-45^{\mathrm{a}}$ \\
$\varnothing$ VS/TS & wt.- $\%$ & 49 & 40 & - & $60-85^{\mathrm{b}}$ \\
\hline
\end{tabular}

${ }^{\mathrm{a}}$ Sperling and Goncalves [37]; ${ }^{\mathrm{b}}$ Tchobanoglous et al. [24]

Table 5. About $49 \mathrm{~g} \mathrm{TS} /(\mathrm{P} \cdot \mathrm{d})$ of screening solids were calculated to be generated with a TS of $40 \mathrm{wt} . \%$. However, a onetime grab sample showed a higher TS content of 49 wt.- $\%$ and a VS/TS of $97.3 \%$. Such a high volatile solid fraction indicates an appropriate biodegradability.

In comparison, the US EPA $[18,21]$ reports, as sole cruise ship reference, amounts of only 6 and $10 \mathrm{~g} \mathrm{TS} /(\mathrm{P} \cdot \mathrm{d})$. No explanation for such low values could be found. A primary sludge generation of about $40 \mathrm{~g} \mathrm{TS} /(\mathrm{P} \cdot \mathrm{d})$ for domestic wastewaters (Table 5) contradict the stated screening solid amounts of the US EPA [18, 21], since the wastewater pollutant loads onboard are up to 3 times higher than domestic wastewaters. On the contrary, rather higher amounts of screening solids are to be expected.

Similar to SS, screening solid volume depends primarily on the water content after screening. In the case of the grabbed sample with 49 wt.-\% TS, $100 \mathrm{~g} /(\mathrm{P} \cdot \mathrm{d})$ screening solids can be expected, which is a negligible amount compared to previous substrates. As a consequence, no further storage volume was considered necessary.

\subsubsection{General overview}

To quantify the total substrate potential onboard, each abovepresented waste stream must be included. Table 6 disaggregates the total specific quantity of organic waste. Per person per day onboard, an amount of $8.8 \mathrm{~kg}$ organic waste was calculated. This results further in 0.467 and $0.411 \mathrm{~kg}$ dry mass and volatile mass, respectively.
Stating person-specific quantities of organic waste facilitates the transfer of findings to different ship sizes. Importantly, the amount of volatile solids (VS) is required for calculating resulting biogas yield per ship. By assuming a 3:1 ratio for passengers and crew members, the average expected substrate quantity onboard can be calculated as VS per day (Eq. 1).

VS cruise ship in total : $V S_{\text {Total }}[\mathrm{kg} / \mathrm{d}]=0.4106^{*} x_{P}$

where $x_{\mathrm{P}}=$ people onboard cruise ship.

Furthermore, Table 6 allows quantifying substrates for passengers and crew members separately using Eqs. 2 and 3.

VS passengers : $V S_{\operatorname{Pax}}[\mathrm{kg} / \mathrm{d}]=0.3525 * x_{P}$

VS crew members : $V S_{\text {Crew }}[\mathrm{kg} / \mathrm{d}]=0.058 * x_{P}$

where $x_{\mathrm{P}}=$ people onboard cruise ship.

For instance, it is expected that an average cruise ship accommodating 3000 people generates $1232 \mathrm{~kg}$ VS per day. Taking water content into account, the individual substrate volumes are as follows: $4095 \mathrm{~kg} \mathrm{FW}, 22,027 \mathrm{~kg} \mathrm{SS}$ and $365 \mathrm{~kg}$ screening solids. In total, 26,486 kg organic waste is produced per day. Due to the high water content, a density of $1 \mathrm{~kg} / \mathrm{L}$ can be assumed, which further results in a volume of $26.5 \mathrm{~m}^{3}$ per day.

\subsubsection{Additional substrates}

Additional organic waste streams onboard which may be also in the focus for anaerobic digestion are grease and black water.
Table 6 Quantities of organic waste onboard cruise ships per person

\begin{tabular}{clllll}
\hline Parameter & Unit & Food waste & Sewage sludge & Screening solids & Total organic waste \\
\hline Generation rate & $\mathrm{kg} / \mathrm{(P} \cdot \mathrm{d})$ & 1.365 & 7.342 & 0.122 & 8.829 \\
& $\mathrm{~kg} \mathrm{TS} /(\mathrm{P} \cdot \mathrm{d})$ & 0.322 & 0.097 & 0.049 & 0.467 \\
& $\mathrm{~kg} \mathrm{VS} /(\mathrm{P} \cdot \mathrm{d})$ & 0.281 & 0.082 & 0.047 & 0.411 \\
TS & $\mathrm{wt.} \%$ & 23.6 & 1.32 & 40.0 & 5.3 \\
VS/TS & $\%$ & 87.3 & 85.1 & 97.3 & 87.9 \\
\hline
\end{tabular}


Table 7 Chemical characterisation of onboard sampled food waste and sewage sludge

\begin{tabular}{|c|c|c|c|c|c|c|c|c|c|c|c|c|c|}
\hline \multirow{2}{*}{$\begin{array}{l}\text { Substrate } \\
\text { Parameter }\end{array}$} & \multirow[b]{2}{*}{ Unit } & \multicolumn{4}{|c|}{ Food waste for proximate analysis } & \multicolumn{4}{|c|}{ Food waste for ultimate analysis } & \multicolumn{4}{|c|}{ Sewage sludge* } \\
\hline & & Mean & Data size & Min & Max & Mean & Data size & Min & $\operatorname{Max}$ & Mean & Data size & Min & Max \\
\hline $\mathrm{TS}$ & wt.-\% & 26.33 & $n=4$ & 16.60 & 30.10 & 25.28 & $n=5$ & 17.90 & 30.20 & 1.32 & $n=3$ & 0.72 & 1.67 \\
\hline $\mathrm{VS} / \mathrm{TS}$ & $\%$ & 91.53 & $n=4$ & 89.16 & 93.54 & 97.75 & $n=5$ & 95.30 & 100.00 & 85.10 & $n=3$ & 83.55 & 87.70 \\
\hline Crude ash & wt.- $\%^{\mathrm{d}}$ & 8.47 & $n=4$ & 6.46 & 10.84 & 2.25 & $n=5$ & 0.00 & 4.70 & 14.90 & $n=3$ & 12.30 & 16.45 \\
\hline Crude protein & wt.- $\%{ }^{\mathrm{d}}$ & 30.91 & $n=4$ & 24.10 & 38.36 & - & & & & - & & & \\
\hline Crude lipids & wt.- $\%^{\text {d }}$ & 20.04 & $n=4$ & 16.87 & 22.45 & - & & & & - & & & \\
\hline Crude fibre & wt.- $\%^{\mathrm{d}}$ & 1.80 & $n=4$ & 0.00 & 4.82 & - & & & & - & & & \\
\hline $\mathrm{N}$-free extracts & wt.- $\%^{\mathrm{d}}$ & 39.10 & $n=4$ & 29.11 & 43.98 & - & & & & - & & & \\
\hline $\mathrm{NH}_{4}-\mathrm{N}^{*}$ & $\mathrm{~g} / \mathrm{kg}$ & 0.14 & $n=4$ & 0.13 & 0.15 & - & & & & 0.36 & $n=3$ & 0.19 & 0.64 \\
\hline $\mathrm{pH}^{*}$ & - & 5.13 & $n=4$ & 4.90 & 5.33 & - & & & & 6.41 & $n=2$ & 6.19 & 6.63 \\
\hline $\mathrm{C}$ & wt.- $\%{ }^{\text {d }}$ & 45.81 & $n=4$ & 43.42 & 47.33 & 49.23 & $n=3$ & 46.90 & 53.20 & - & & & \\
\hline $\mathrm{N}$ & wt.- $\%^{\mathrm{d}}$ & 5.72 & $n=4$ & 4.46 & 7.10 & 4.72 & $n=5$ & 4.00 & 6.30 & 9.16 & $n=3$ & 7.03 & 10.82 \\
\hline $\mathrm{S}$ & wt.- $\%^{\mathrm{d}}$ & 0.15 & $n=4$ & 0.12 & 0.19 & 0.26 & $n=5$ & 0.23 & 0.29 & - & & & \\
\hline $\mathrm{H}$ & wt.- $\%^{\mathrm{d}}$ & 6.81 & $n=4$ & 6.63 & 7.06 & 6.91 & $n=5$ & 6.79 & 7.07 & - & & & \\
\hline $\mathrm{O}$ & wt.- $\%{ }^{\text {d }}$ & 33.36 & $n=4$ & 30.71 & 35.11 & 37.27 & $n=3$ & 33.20 & 41.80 & - & & & \\
\hline $\mathrm{C} / \mathrm{N}$ & - & 8.20 & $n=4$ & 6.50 & 9.74 & 10.36 & $n=3$ & 7.56 & 12.37 & - & & & \\
\hline $\mathrm{COD}_{\text {theo }}$ & $\mathrm{g} / \mathrm{kg}$ & 382 & \multicolumn{3}{|c|}{ Based on average } & 402 & \multicolumn{3}{|c|}{ Based on average } & 21.5 & $n=3$ & 8.90 & 28.62 \\
\hline $\mathrm{COD}_{\text {theo }}$ & $\mathrm{g} / \mathrm{kg} \mathrm{VS}$ & 1586 & \multicolumn{3}{|c|}{ Based on average } & 1627 & \multicolumn{3}{|c|}{ Based on average } & 1828 & $n=3$ & 1480 & 2047 \\
\hline
\end{tabular}

*measured; ${ }^{\mathrm{d}}$ dry base

Grease consists primarily of galley waste oil and grease from the separation process of galley wastewater. Both investigated ship types collect grease in oil drums or containers for subsequent disposal at the port. Once onshore, a common and environmentally friendly valorisation route can be implemented through conversion of grease into biodiesel. An inferior route would be the incineration onboard, as reported by Hung et al. [41]. Due to already appropriate handling of ship-generated grease, there is no need for an alternative disposal route. Accordingly, it is not considered as potential substrate in this study.

Black water (BW) is highly concentrated wastewater (COD $>6000 \mathrm{mg} / \mathrm{L}, n=5$, self-measured) mainly from vacuum toilets, urinals and sickbay drainage with an average generation rate of about $32 \mathrm{~L} /(\mathrm{P} \cdot \mathrm{d})$ [40]. No crucial differences in
BW composition from onshore vacuum systems can be identified, e.g. Wendland [42].

For the adequate treatment of BW onboard modern cruise ships, substantial energy amounts are necessary. Considering $\mathrm{AD}$ as a pre-treating step has the potential to decrease the energy consumption of the WWTP, reduce SS generation and simultaneously gain energy-rich biogas. However, currently sufficient onboard treatment of BW is implemented. On that account, this study does not consider AD of BW in more detail. A comprehensive study that deals with the feasibility of combined AD of BW and FW onshore was carried out by Wendland [42]. Nevertheless, SS produced from BW during the aerobic treatment process is still included in this investigation. For the future, AD of BW could be considered

Table 8 Biogas yield and composition of substrates onboard cruise ships

\begin{tabular}{|c|c|c|c|c|c|c|c|c|c|c|c|}
\hline \multirow{3}{*}{$\begin{array}{l}\text { Substrate } \\
\text { Parameter }\end{array}$} & \multirow[b]{3}{*}{ Unit } & \multicolumn{10}{|c|}{ Mono-digestion } \\
\hline & & \multicolumn{4}{|c|}{ Food waste } & \multicolumn{4}{|c|}{ Sewage sludge } & \multicolumn{2}{|c|}{ Screening solids } \\
\hline & & Mean & Data size & Min & $\operatorname{Max}$ & Mean & Data size & Min & $\operatorname{Max}$ & Mean & Data size \\
\hline $\mathrm{y}_{\text {Biogas }}$ & $\mathrm{L} / \mathrm{kg} \mathrm{VS}$ & 620 & $n=7$ & 512 & 688 & 314 & $n=2$ & 313 & 315 & 570 & $n=1$ \\
\hline $\mathrm{V}_{\mathrm{CH} 4, \text { Biogas }}$ & Vol.- $\%$ & 69.4 & $n=3$ & 67.3 & 72.2 & 76.2 & $n=1$ & - & & 65.92 & $n=1$ \\
\hline $\mathrm{y}_{\text {Methane }}$ & $\mathrm{L} / \mathrm{kg} \mathrm{VS}$ & 430.8 & \multicolumn{3}{|c|}{ Based on average } & 239.4 & \multicolumn{3}{|c|}{ Based on average } & 376.0 & - \\
\hline $\mathrm{y}_{\text {Methane,theo,COD }}$ & $\mathrm{L} / \mathrm{kg} \mathrm{VS}$ & 569 & \multicolumn{3}{|c|}{ Based on average } & 640 & \multicolumn{3}{|c|}{ Based on average } & - & \\
\hline
\end{tabular}

$\mathrm{y}_{\text {Biogas }}$ : specific biogas yield; $\mathrm{y}_{\text {Methane }}$ specific methane yield; $\mathrm{V}_{\mathrm{CH} \text {,Biogas }}$ : methane content; $\mathrm{y}_{\text {Methan,theo,COD: }}$ theoretical specific methane yield based on COD 
Fig. 7 Simplified mass balance for a biogas plant onboard a cruise ship accommodating 3000 people

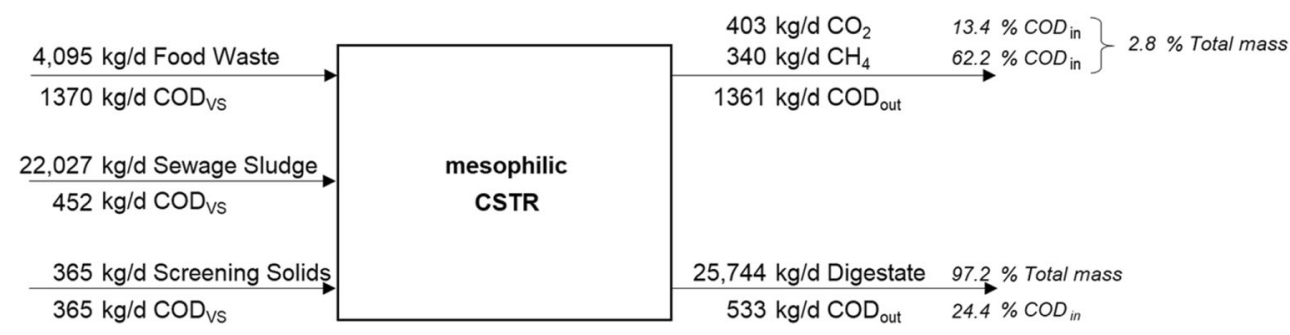

for new and revised onboard WWTP. It is necessary to note that AD of BW will have a significant impact on the WWTP, due to a decreased COD load and steady total nitrogen load.

\subsection{Chemical characterisation of substrates}

The analytical results for the chemical characterisation of FW and SS samples are listed in Table 7. FW samples were examined by means of proximate analysis and ultimate analysis. For the proximate analysis the main components protein, lipids and carbohydrates were, on a dry basis, 30.91 wt.-\%, 20.04 wt.-\% and 40.9 wt.-\%, respectively.

The heterogeneity of FW caused a carbon content ranging from 43.42 to 53.20 dry wt.-\%. In addition, nitrogen content varied from 4.00 to 7.10 dry wt. $\%$. The $\mathrm{C} / \mathrm{N}$ ratio of $\mathrm{FW}$ was between 6.5 and 12.37. In terms of elementary composition, as well as the chemical oxygen demand (COD) of about $1600 \mathrm{~g} \mathrm{COD} / \mathrm{kg}$ VS, FW showed a similar range for landbased investigations by Heo et al. [43], Zhang et al. [44], Curry and Pillay [45] and Fisgativa et al. [46]. However, those authors reported higher $\mathrm{C} / \mathrm{N}$ ratios in a range from 13 to 18 . A possible explanation for the lower $\mathrm{C} / \mathrm{N}$ ratios might be the extensive and surplus provision of nitrogen-rich food onboard, especially considering higher meat and protein content.

A total nitrogen $(\mathrm{TN})$ content of $1.21 \mathrm{~g} / \mathrm{kg}$ on average for SS resulted in a proportion of $9.16 \mathrm{wt} .-\%$, on a dry basis. Furthermore, a mean COD content of $21.5[\mathrm{~g} \mathrm{COD} / \mathrm{kg}]$ or 1.828 [g COD/kg VS] was measured. Avellaneda et al. [47] reported about biosolids as a mixture of SS and screening solids onboard cruise ships. A similar mean value for TN was presented while the TSS mean value was slightly higher.

Common $\mathrm{C} / \mathrm{N}$ ratios for primary and excess sludge vary from 6 to 8 according to Cheng et al. [48], Heo et al. [43], Elsayed et al. [49] and Ahn and Speece [50]. Moreover, those authors specified TN contents on a dry basis of $4 \%$ and $7 \%$. Thus, the expected $\mathrm{C} / \mathrm{N}$ ratio of the sampled SS (TN: ca. 9 wt. $-\%^{\mathrm{d}}$ ) can be assumed to be in the range of 5. This low ratio is essentially caused by the unforeseen presence of a significantly high amount of ammonium nitrogen which indicates insufficient nitrification in the WWTP onboard.

Even if no specific laboratory analyses have been performed for the screening solids from mechanical wastewater treatment, their characteristics can be assumed to be similar to conventional primary sludge, due to origin, high content of volatile solids and high biogas potential. In accordance with Park et al. [51], the substrate accessibility of screening solids can be classified higher than SS but lower than FW.

Overall, both investigated substrates revealed a lower C/N ratio than the recommended ratio of 20 to 30 for an optimal $\mathrm{AD}$ process [52]. For the AD of SS and screening solids, codigestion with $\mathrm{FW}$ would nonetheless lead to an enhanced $\mathrm{C} /$ $\mathrm{N}$ ratio.

\subsection{Gas yield and mass balance}

The potential biogas and methane quantities for a whole cruise ship can be predicted by considering the specific biogas yields of the sampled substrates and their given quantities. Table 8 details the specific biogas and methane yields from the conducted biogas potential tests for FW, SS and screening solids. According to these experiments, the specific biogas yields were $0.620 \mathrm{~m}^{3} / \mathrm{kg}$ VS for FW and $0.314 \mathrm{~m}^{3} / \mathrm{kg}$ VS for SS with a methane content of $69.45 \%$ and $76.22 \%$, respectively. The biogas potential of screening solids was $0.570 \mathrm{~m}^{3} / \mathrm{kg}$ VS with a methane content of $65.92 \%$. To evaluate the gained biogas data, the theoretical methane yield of $0.57 \mathrm{~m}^{3} / \mathrm{kg} \mathrm{VS}$ and $0.64 \mathrm{~m}^{3} / \mathrm{kg}$ VS was derived for FW and SS, respectively. The biodegradability of $76 \%$ for FW was about two times higher than for SS with $37 \%$ when considering the theoretical methane yields as the basis. Heo et al. [43] reported a biodegradability of $86 \%$ and $29 \%$ for similar substrates in BMP tests with a well-adapted inoculum by using Buswell's equation to determine the theoretical methane yield [53]. The same result for FW could be proven by using Buswell's equation.

As a preliminary mass balance, Fig. 7 specifies the input and output streams of a biogas plant onboard the reference cruise ship, accommodating 3000 people. About $743 \mathrm{~kg}$ /day biogas or $340 \mathrm{~kg}$ /day methane and $25,744 \mathrm{~kg}$ /day digestate will result when the daily available organic waste amount of $26,487 \mathrm{~kg} /$ day is fed. The AD process reduces the total input mass by $3 \%$ while the corresponding $\mathrm{COD}_{\text {in }}$ load is diminished by $75.6 \%$ with $62.2 \%$ assigning to the methane production. Even though AD reduces merely little the total mass of the organic waste, only a quarter of the original COD load remains inside the digestate.

In contrast to the present handling of organic waste onboard cruise ships, AD technology reduces the organic load of organic waste significantly while converting organic matter 
Fig. 8 Biogas potential test for ship-generated FW, SS and a corresponding mix

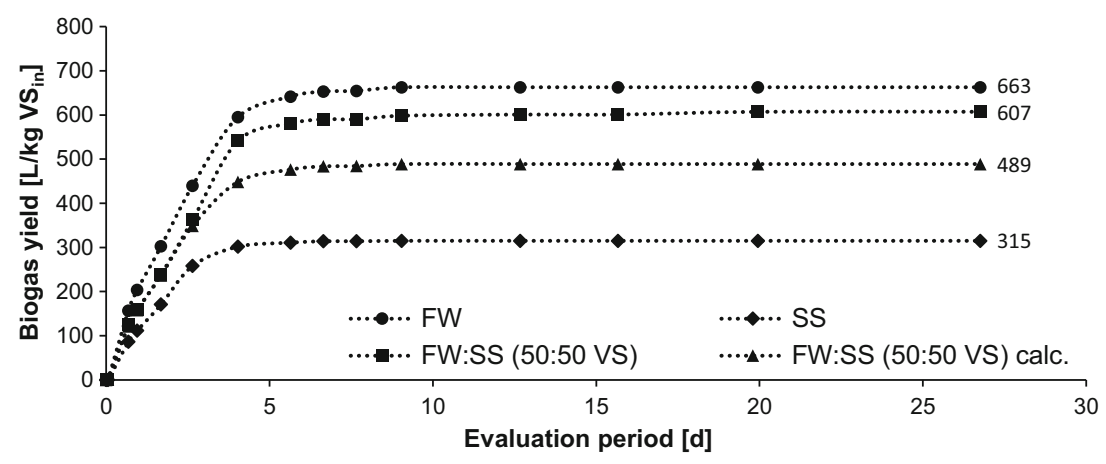

into renewable fuel for a direct use onboard. Alternative processing steps as drying and incineration of organic waste are demanding supplementary energy and increase the overall $\mathrm{CO}_{2}$ emissions without generating any advantages, except for complete elimination.

No significant differences for FW onboard cruise ships were revealed when compared to land-based literature, e.g. Zhang et al. [54] reported an average yield of $435 \mathrm{~L} \mathrm{CH}_{4} / \mathrm{kg}$ VS. Slightly higher methane yields were reported by Banks and Heaven [52] for typical food remains. Additionally, conducted biogas potential tests showed similar biogas yields ( $339 \mathrm{~L} / \mathrm{kg} \mathrm{VS}, n=3$ ) for waste-activated sludge from the WWTP Herrenhausen. However, the land-based scientific literature reports higher [55] as well as lower [51, 56] biogas and methane yields for waste-activated sludge (here: SS). A typical range of 190 to $240 \mathrm{~L} \mathrm{CH}_{4} / \mathrm{kg}$ VS is referred by Bachmann [57]. Clearly higher methane yields (314-400 L CH$/ \mathrm{kg} \mathrm{VS)}$ for primary sludge are in line with the gained methane yield for screening solids [57]. These findings strengthen the assumption that screening solids can be classified as shipgenerated primary sludge.

Variations in biogas and methane yields may be based on performed BMP tests with inocula which are more or less adapted to the investigated substrates. Especially the heterogeneity of FW leads to a wide range of results. Overall, no divergent findings on the biogas potential of ship-generated organic waste were gained, compared to ashore.

Nevertheless, cruise ships possess a unique opportunity to implement combined AD of organic waste streams, without costly substrate transportation. Anaerobic co-digestion involves at least two or more substrates and is applied to utilise spare capacities, to increase the biogas productivity or to stabilise the biological process. Xie et al. [58] reported that co-digestion of FW and SS significantly improves specific methane yields. Their results were two times higher compared to mono-digestion experiments. Similar findings are also reported by Sosnowski et al. [59]. Dai et al. [60] came to another conclusion and ascertained no effect on specific methane yield depending on mono- or combined digestion or certain mixing ratios. However, the authors emphasised the positive effects of co-digestion on process stability (e.g. compensation of $\mathrm{Na}^{+}-$ inhibition) and noted additional biogas yields by adding FW to the sludge digestion process.

To prove the findings above, anaerobic digestion tests for $\mathrm{FW}, \mathrm{SS}$ and a mixture of the same FW and SS were performed (Fig. 8). While the mono-digested FW and SS are in the range of the reported biogas potential, the mixture (50:50 VS) achieved $607 \mathrm{~L} / \mathrm{kg}$ VS. This is an improvement of about $24 \%$, compared to the calculated yield of $489 \mathrm{~L} / \mathrm{kg}$ VS on the basis of mono-digestion. According to Heo et al. [43], a VS-mixing ratio of 50:50, for FW and SS ensures high methane yields and stable process conditions. The situation onboard reveals a FW:SS:screening solids ratio of 68:20:12 if all accruing substrates are applied and a ratio of 77:23 if only FW and SS are considered.

Assuming that an optimal mono-digestion process of all substrates takes place, $227.1 \mathrm{~L}$ of biogas and $158.5 \mathrm{~L}$ of methane per person per day can be produced onboard. The resulting thermal power output is thus $66 \mathrm{~W}$ per person, given a calorific value of $10 \mathrm{kWh} / \mathrm{m}^{3}$ for methane. Table 9 provides a detailed overview.

For instance, an average cruise ship with 3000 people onboard would potentially provide $198 \mathrm{~kW}$ thermal power. The available power through $\mathrm{AD}$ of all available substrates
Table 9 Substrate specific biogas and methane yields per person per day $\left(\mathrm{y}_{\text {Biogas, }} \mathrm{p} / \mathrm{y}_{\text {Methane,p }}\right)$ and the corresponding thermal power $\mathrm{P}_{\mathrm{p}, \text { th }}$ and thermal energy $\mathrm{E}_{\mathrm{P}, \mathrm{th}}$ equivalent for separated monodigestion

\begin{tabular}{lllllr}
\hline Parameter & Unit & Food waste & Sewage sludge & Screening solids & Total \\
\hline y $_{\text {Biogas,p }}$ & $\mathrm{L} /(\mathrm{d} \cdot \mathrm{P})$ & 174.2 & 25.9 & 27.0 & 227.1 \\
$\mathrm{y}_{\text {Methane,p }}$ & $\mathrm{L} /(\mathrm{d} \cdot \mathrm{P})$ & 121.0 & 19.7 & 17.8 & 158.5 \\
$\mathrm{P}_{\mathrm{p}, \mathrm{th}}$ & $\mathrm{W} / \mathrm{P}$ & 50.4 & 8.2 & 7.4 & 66.0 \\
$\mathrm{E}_{\mathrm{P}, \mathrm{th}}$ & $\mathrm{kWh} / \mathrm{P} \cdot \mathrm{d}$ & 1.2 & 0.2 & 0.2 & 1.6 \\
\hline
\end{tabular}


Fig. 9 Biogas and methane yields and corresponding thermal power depending on the number of people onboard

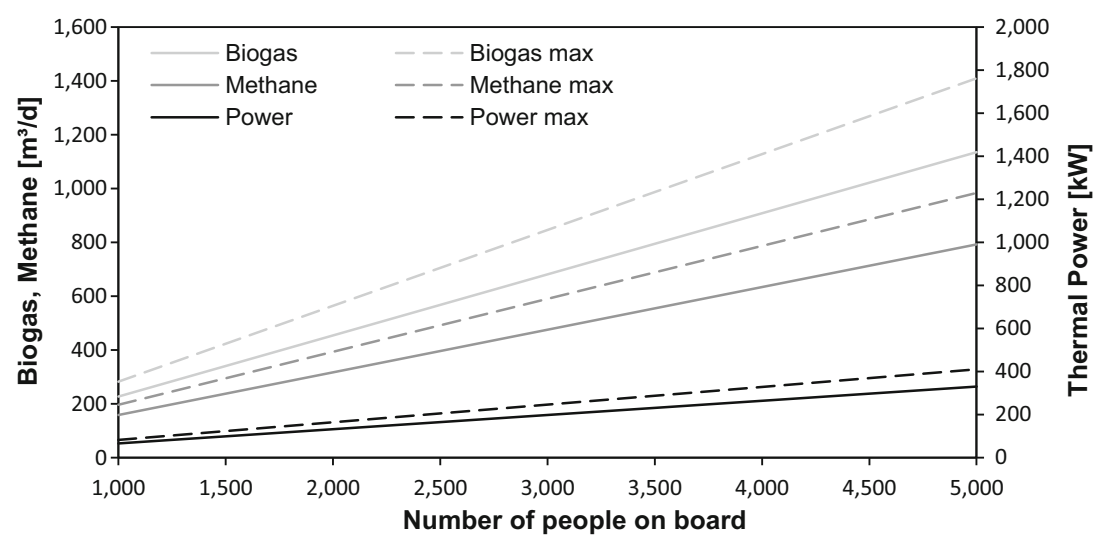

can make a significant contribution towards a more efficient ship energy system. Furthermore, the energy conversion directly onboard prevents shipping companies from discharging untreated organic waste into the marine environment. Nonetheless, the onboard implementation of a large-scale biogas plant is a challenging undertaking, considering that, to date, no experience on system integration or operation exists while strict regulations for the onboard gas handling have to be met. However, putting AD technology into action would be another contribution towards minimising ship emissions. About $76 \%$ of the COD load of organic waste will be diminished if AD technology is applied.

Profound findings were provided with regard to quantities and characteristics of suitable substrates for onboard biogas generation, such as food waste, sewage sludge and screening solids. Per person per day, potentially $159 \mathrm{~L}$ of methane can be produced, which results in $66 \mathrm{~W}$ per person and $198 \mathrm{~kW}$ per reference cruise ship. The circumstances onboard allow the application of co-digestion of organic waste streams. It could be proven that this combined digestion leads to methane biogas yields and improves process stability. Anaerobic digestion tests revealed an improvement of $24 \%$ in biogas yield when applying co-digestion $\left(\mathrm{FW}_{\mathrm{VS}}: \mathrm{SS}_{\mathrm{VS}}=50: 50\right)$ and led to a thermal power supply of up to $82 \mathrm{~W} / \mathrm{P}$. This may seem small in view of the overall energy consumption of about $2000 \mathrm{~W} / \mathrm{P}$, but it is nevertheless an additional contribution to improved environmental protection onboard.

In periods of lower heat demand, e.g. in summer or while cruising through the Caribbean, up to $28 \%$ of the total heat demand onboard could be covered through onboard AD of organic waste. Applying the findings of this analysis to an average cruise ship accommodating 3000 people, the potentially provided thermal power would be up to $246 \mathrm{~kW}$, equal to the theoretical energy content of $537 \mathrm{~kg}$ heavy fuel oil (11 $\mathrm{kWh} / \mathrm{kg}$ ) per day. Depending on the efficiency of the ship engines, even higher substitution rates can be achieved. Sticking to the theoretical energy content, around $196 \mathrm{t}$ fuel could be compensated per ship per year or $65 \mathrm{~kg}$ heavy fuel oil per person onboard per year could be substituted. However,

obic digestion, organic waste generated onboard cruise ships 
considering a decreasing passenger FW generation through an improved restaurant service would reduce providable power.

The key criterion for a feasible implementation of an anaerobic digestion plant onboard is its space requirement. This study even permits initial statements to be made on the design of possible AD systems onboard. The preparatory work described here is a prerequisite for explicit, robust, adapted and verified design suggestions for onboard $\mathrm{AD}$ reactors. A rough estimated initial reactor size of $50 \mathrm{~L} / \mathrm{P}$ can be evaluated as a manageable and implementable size onboard, especially when the environmental systems onboard (cruise ships $1 \& 2$ ) provides about $17 \mathrm{~L} / \mathrm{P}$ storage capacity for organic waste and several hundreds of litres of storage capacity per person for the wastewater system or the ballast water system. Further issues will have to be tackled to support the AD concept, such as the proper implementation of gas use and the environmentally friendly handling of digestate.

Acknowledgements This sub-project is undertaken by the Institute for Sanitary Engineering and Waste Management (ISAH), Leibniz University Hanover. We would like to thank our project partner Carnival Maritime for extensive provision/support regarding data on cruise ships and for access to their vessels, and the funding body and the Projektträger Jülich for the opportunity to carry out the work described here.

Code availability Not applicable.

Authors' contributions K. Schumüller: methodology; investigation; validation; writing — original draft; visualization; project administration

D. Weichgrebe: writing — review and editing

S. Köster: conceptualization; writing - review and editing; supervision

Funding Open Access funding enabled and organized by Projekt DEAL. The research and development project "Cruise Liners: Efficient onboard anaerobic digestion of organic wastes for energy recovery" (CLEAN) is funded by the Federal Ministry for Economic Affairs and Energy (BMWi), Germany. The results presented here originate from the subproject "Basic investigation and process design for the anaerobic digestion of organic residues onboard cruise ships" (CLEAN-PROCESS; Grant No. FKZ 03SX437C).

Data availability Further information on the project can be found at www.clean-biogas.de.

\section{Compliance with ethical standards}

Conflict of interest The authors declare that there is no conflict of interest.

Open Access This article is licensed under a Creative Commons Attribution 4.0 International License, which permits use, sharing, adaptation, distribution and reproduction in any medium or format, as long as you give appropriate credit to the original author(s) and the source, provide a link to the Creative Commons licence, and indicate if changes were made. The images or other third party material in this article are included in the article's Creative Commons licence, unless indicated otherwise in a credit line to the material. If material is not included in the article's Creative Commons licence and your intended use is not permitted by statutory regulation or exceeds the permitted use, you will need to obtain permission directly from the copyright holder. To view a copy of this licence, visit http://creativecommons.org/licenses/by/4.0/.

\section{References}

1. CLIA (2019) 2019 State of the Industry: CRUISE TRENDS \& INDUSTRY OUTLOOK. https://cruising.org/news-and-research/ research/2018/december/2019-state-of-the-industry. Accessed 08 Apr 2020

2. Wilewska-Bien M, Granhag L, Andersson K (2020) Pathways to reduction and efficient handling of food waste on passenger ships: from Baltic Sea perspective. Environ Dev Sustain 22(1):217-230

3. Sanches V, Aguiar M, de Freitas M, Pacheco E (2020) Management of cruise ship-generated solid waste: a review. Mar Pollut Bull 151:110785

4. Toneatti L, Deluca C, Fraleoni-Morgera A, Pozzetto D (2020) Rationalization and optimization of waste management and treatment in modern cruise ships. Waste Manag 118:209-218. https:// doi.org/10.1016/j.wasman.2020.08.018

5. Vaneeckhaute C, Fazli A (2020) Management of ship-generated food waste and sewage on the Baltic Sea: a review. Waste Manag 102:12-20. https://doi.org/10.1016/j.wasman.2019.10.030

6. Nghiem L, Koch K, Bolzonella D, Drewes J (2017) Full scale codigestion of wastewater sludge and food waste: bottlenecks and possibilities. Renew Sust Energ Rev 72:354-362. https://doi.org/ 10.1016/j.rser.2017.01.062

7. Banks et al. (2018) FOOD WASTE DIGESTION: Anaerobic Digestion of Food Waste for a Circular Economy. https://www. ieabioenergy.com/wp-content/uploads/2018/12/Food-waste_ WEB_END.pdf

8. (2011) Amendments to the Annex of the Protocol of 1978 relating to the International Convention for the Preventation of Pollution from Ships, 1973 (Revised MARPOL Annex V): MEPC.201(62). International Maritime Organization

9. Carnival Corporation \& plc (2016) Sustainability - From Ship To Shore: FY2016 Sustainability Report. https://www. carnivalcorporation.com/transparency-and-reporting/sustainabilityreports. Accessed 25 Jan 2020

10. Strazza C, Magrassi F, Gallo M, Del Borghi A (2015) Life cycle assessment from food to food: a case study of circular economy from cruise ships to aquaculture. Sustainable Production and Consumption 2:40-51. https://doi.org/10.1016/j.spc.2015.06.004

11. Alaska Department of Environmental Conservation (2012) CRUISE SHIP WASTEWATER: 2009-2012 SCIENCE ADVISORY PANEL - PRELIMINARY REPORT

12. CLIA (2019) CLIA Releases 2019 Environmental Technologies and Practices Report. https://cruising.org/news-and-research/pressroom/2019/september/clia-releases-2019-environmentaltechnologies-and-practices-report. Accessed 08 Apr 2020

13. (2015) International Code of Safety for Ships using Gases or Other Low-Flashpoint Fuels: IGF-CODE. International Maritime Organization

14. Wilewska-Bien M, Granhag L, Andersson K (2016) The nutrient load from food waste generated onboard ships in the Baltic Sea. Mar Pollut Bull 105(1):359-366. https://doi.org/10.1016/j. marpolbul.2016.03.002

15. Olson P (1995) Handling of waste in ports. Mar Pollut Bull 1994(29):284-295

16. EMSA (2007) Study on ships producing reduced quantities of ships generated waste - present situation and future opportunities to 
encourage the development of cleaner ships: final report. European Maritime Safety Agency

17. Polglaze $J$ (2003) Can we always ignore ship-generated food waste? Mar Pollut Bull 46(1):33-38. https://doi.org/10.1016/ S0025-326X(02)00324-7

18. U.S. EPA (2006) Sampling Episode Report - Princess Cruise Lines - Island Princess: Sampling Episode 6505, Washington, DC

19. U.S. EPA (2006) Sampling Episode Report - Holland America Oosterdam: Sampling Episode 6506, Washington, DC

20. U.S. EPA (2006) Sampling Episode Report - Norwegian Star: Sampling Episode 6504, Washington, DC

21. U.S. EPA (2006) Sampling Episode Report - Holland America Veendam: Sampling Episode 6503, Washington, DC

22. DWA (2016) Bemessung von einstufigen Belebungsanlagen (Design of single-stage activated sludge plants), Juni 2016. DWA-Arbeitsblatt, A 131. Deutsche Vereinigung für Wasserwirtschaft Abwasser und Abfall, Hennef, Germany

23. S. Köster, L. Westhof, L. Keller (2016) Stand der Technik der Abwasserreinigung an Bord von Kreuzfahrtschiffen (State of the art of wastewater treatment on cruise ships). gwf Wasser + Abwasser: 528-537

24. Tchobanoglous G, Stensel D, Tsuchihashi R, Burton F, Abu-Orf M, Bowden G, Pfrang W (2014) Wastewater engineering: treatment and resource recovery, 5th edn. McGraw-Hill Education, New York

25. Henze M, Comeau Y (2008) Wastewater characterization. In: Henze M (ed) Biological wastewater treatment: principles, modelling and design. IWA Pub, London, pp 33-52

26. TUI Cruises \& Futouris (2019) Reduction of food waste on cruise ships: A project report \& implementation guide

27. European Committee for Standardization (2001) EN 12880:2001 Characterization of sludges - Determination of dry residue and water content

28. European Committee for Standardization (2012) EN 15935:2012 Sludge, treated biowaste, soil and waste - Determination of loss on ignition

29. Straka F, Jenicek P, Zabranska J et al. (eds) (2007) Anaerobic fermentation of biomass and waste with respect to sulfur and nitrogen contents in treated materials

30. OECD (1992) Guideline for testing of chemicals: test no. 301: ready biodegradability. https://doi.org/10.1787/9789264070349-en

31. (2016) Fermentation of organic materials - characterization of the substrate, sampling, collection of material data, fermentation tests

32. Holliger C, Alves M, Andrade D, Angelidaki I, Astals S, Baier U, Bougrier C, Buffière $\mathrm{P}$, Carballa $\mathrm{M}$, de Wilde V, Ebertseder F, Fernández B, Ficara E, Fotidis I, Frigon J-C, de Laclos H, Ghasimi D, Hack G, Hartel M, Heerenklage J, Horvath I, Jenicek P, Koch K, Krautwald J, Lizasoain J, Liu J, Mosberger L, Nistor M, Oechsner H, Oliveira J, Paterson M, Pauss A, Pommier S, Porqueddu I, Raposo F, Ribeiro T, Rüsch Pfund F, Strömberg S, Torrijos M, van Eekert M, van Lier J, Wedwitschka H, Wierinck I (2016) Towards a standardization of biomethane potential tests. Water Sci Technol 74(11):2515-2522. https://doi.org/10.2166/ wst.2016.336

33. Carnival Corporation \& plc (2018) 2017 Annual Report. https:// www.carnivalcorp.com/financial-information/annual-reporting/. Accessed 16 Sep 2019

34. Sustainable Restaurant Association (2010) Too good to waste: restaurant food waste survey report (2010). UK, London

35. Papargyropoulou E, Steinberger J, Wright N, Lozano R, Padfield R, Ujang Z (2019) Patterns and causes of food waste in the hospitality and food service sector: food waste prevention insights from Malaysia. Sustainability 11(21):6016. https://doi.org/10.3390/ su11216016

36. Jörissen J, Priefer C, Bräutigam K-R (2015) Food waste generation at household level: results of a survey among employees of two
European research centers in Italy and Germany. Sustainability 7(3):2695-2715. https://doi.org/10.3390/su7032695

37. Sperling M, Goncalves R (2007) Sludge characteristics and production. In: Fernandes F (ed) Andreoli CV, Sperling Mv. Sludge Treatment and Disposal. IWA Publishing, London

38. Friedler E, Butler D, Alfiya Y (2013) Wastewater composition. In: Larsen TA, Udert KM, Lienert J (eds) Source separation and decentralization for wastewater management. IWA Publishing

39. (2004) Revised Annex IV of MARPOL 73/78: RESOLUTION MEPC.115(51)

40. U.S. EPA (2008) U.S. Environmental Protection Agency: Cruise Ship Discharge Assessment Report. https://www.epa.gov/vesselsmarinas-and-ports/cruise-ship-discharges-and-studies\#access reports. Accessed 25 Jan 2020

41. Hung Y, Wang L, Wang MHS, Shammas N, Chen J (2017) Waste treatment in the service and utility industries. CRC Press, Advances in Industrial and Hazardous Wastes Treatment

42. Wendland C (2009) Anaerobic digestion of blackwater and kitchen refuse. Technische Universität Hamburg-Harbug, Dissertation http://doku.b.tu-harburg.de/volltexte/2009/553/

43. Heo N, Park S, Kang H (2004) Effects of mixture ratio and hydraulic retention time on single-stage anaerobic co-digestion of food waste and waste activated sludge. J Environ Sci Health A 39(7): 1739-1756. https://doi.org/10.1081/ESE-120037874

44. Zhang L, Lee Y-W, Jahng D (2011) Anaerobic co-digestion of food waste and piggery wastewater: focusing on the role of trace elements. Bioresour Technol 102(8):5048-5059. https://doi.org/10. 1016/j.biortech.2011.01.082

45. Curry N, Pillay P (2012) Biogas prediction and design of a food waste to energy system for the urban environment. Renew Energy 41:200-209. https://doi.org/10.1016/j.renene.2011.10.019

46. Fisgativa H, Marcilhac C, Girault R, Daumer M-L, Trémier A, Dabert P, Béline F (2018) Physico-chemical, biochemical and nutritional characterisation of 42 organic wastes and residues from France. Data in Brief 19:1953-1962. https://doi.org/10.1016/j.dib. 2018.06.050

47. Avellaneda P, Englehardt J, Olascoaga J, Babcock E, Brand L, Lirman D, Rogge W, Solo-Gabriele H, Tchobanoglous G (2011) Relative risk assessment of cruise ships biosolids disposal alternatives. Mar Pollut Bull 62(10):2157-2169. https://doi.org/10.1016/j. marpolbul.2011.07.006

48. Cheng J, Ding L, Lin R, Yue L, Liu J, Zhou J, Cen K (2016) Fermentative biohydrogen and biomethane co-production from mixture of food waste and sewage sludge: effects of physiochemical properties and mix ratios on fermentation performance. Appl Energy 184:1-8. https://doi.org/10.1016/j.apenergy.2016.10.003

49. Elsayed M, Andres Y, Blel W, Gad A, Ahmed A (2016) Effect of VS organic loads and buckwheat husk on methane production by anaerobic co-digestion of primary sludge and wheat straw. Energy Convers Manag 117:538-547. https://doi.org/10.1016/j.enconman. 2016.03.064

50. Ahn Y, Speece R (2006) Elutriated acid fermentation of municipal primary sludge. Water Res 40(11):2210-2220. https://doi.org/10. 1016/j.watres.2006.03.022

51. Park K, Jang H, Park M-R, Lee K, Kim D, Kim Y (2016) Combination of different substrates to improve anaerobic digestion of sewage sludge in a wastewater treatment plant. Int Biodeterior Biodegradation 109:73-77. https://doi.org/10.1016/j.ibiod.2016. 01.006

52. Banks C, Heaven S (2013) Optimisation of biogas yields from anaerobic digestion by feedstock type. In: Wellinger A, Baxter D, Murphy J (eds) The biogas handbook: Science, production and applications. Woodhead Publishing Limited, Oxford

53. Tchobanoglous G, Theisen H, Vigil S (1993) Integrated solid waste management: engineering principles and management issues, 
International edn McGraw-Hill series in water resources and environmental engineering

54. Zhang R, El-Mashad H, Hartman K, Wang F, Liu G, Choate C, Gamble P (2007) Characterization of food waste as feedstock for anaerobic digestion. Bioresour Technol 98(4):929-935. https://doi. org/10.1016/j.biortech.2006.02.039

55. Luostarinen S, Luste S, Sillanpää M (2009) Increased biogas production at wastewater treatment plants through co-digestion of sewage sludge with grease trap sludge from a meat processing plant. Bioresour Technol 100(1):79-85. https://doi.org/10.1016/j. biortech.2008.06.029

56. Athanasoulia E, Melidis P, Aivasidis A (2012) Optimization of biogas production from waste activated sludge through serial digestion. Renew Energy 47:147-151. https://doi.org/10.1016/j.renene. 2012.04.038

57. N. Bachmann (2015) Sustainable biogas production in municipal wastewater treatment plants. IEA Bioenergy

58. Xie S, Wickham R, Nghiem L (2017) Synergistic effect from anaerobic co-digestion of sewage sludge and organic wastes. Int Biodeterior Biodegradation 116:191-197. https://oi.org/10.1016/ j.ibiod.2016.10.037

59. Sosnowski P, Klepacz-Smolka A, Kaczorek K, Ledakowicz S (2008) Kinetic investigations of methane co-fermentation of sewage sludge and organic fraction of municipal solid wastes. Bioresour Technol 99(13):5731-5737. https://doi.org/10.1016/j. biortech.2007.10.019

60. Dai X, Duan N, Dong B, Dai L (2013) High-solids anaerobic codigestion of sewage sludge and food waste in comparison with mono digestions: stability and performance. Waste Manag 33(2): 308-316. https://doi.org/10.1016/j.wasman.2012.10.018

61. Baldi F, Ahlgren F, Nguyen T-V, Thern M, Andersson K (2018) Energy and exergy analysis of a cruise ship. Energies 11(10):2508. https://doi.org/10.3390/en 11102508

62. S. Köster, Technische Universität Hamburg-Harburg, Institut für Abwasserwirtschaft und Gewässerschutz, L. Westhof (2016) Sustainable solutions for wastewater treatment and reuse on cruise ships (NAUTEK) : technologies for wastewater treatment and micropollutants removal on cruise ships. Technische Universität Hamburg, Dekanat Bauwesen, Institut für Abwasserwirtschaft und Gewässerschutz

Publisher's Note Springer Nature remains neutral with regard to jurisdictional claims in published maps and institutional affiliations. 